\title{
Value Relevance of Accounting Information in Explaining Stock Returns in Sri Lanka
}

\author{
Yathra Mullage Chithrasheeli Gunaratne ${ }^{1}$, \& P A Niluka Surangi Anuradha ${ }^{2}$ \\ ${ }^{1}$ Faculty of Management, Uva Wellassa University, Badulla, Sri Lanka \\ ${ }^{2}$ Faculty of Management Studies and Commerce, Sri Jayewardhenepure University, Nugegoda, Sri Lanka \\ Correspondence: Yathra Mullage Chithrasheeli Gunaratne, Faculty of Management, Uva Wellassa University, Sri \\ Lanka. Tel: 94-718-285-587. E-mail: gunaratneymc@gmail.com
}

Received: August 1, 2017

doi:10.5539/ijbm.v12n10p223
Accepted: August 20, $2017 \quad$ Online Published: September 17, 2017

URL: https://doi.org/10.5539/ijbm.v12n10p223

\begin{abstract}
The value relevance of accounting information is an important area in accounting researches. However the literature provides contradictory conclusions on the value relevance of accounting information in different stock exchanges and there is a very limited knowledge in this regard in Sri Lankan context. Hence this study endeavored to investigate the value relevance of accounting information in explain stock returns considering three traditional accounting performance measures: Earnings Per Share (EPS), Return on Equity (ROE) and Return on Investment (ROI) as the proxy for accounting information. The study was conducted with the hypothesis that the traditional accounting performance measures are significant in explaining stock returns in Sri Lanka. A sample of 1695 firm year observations were used for the study covering 113 companies in Colombo Stock Exchange for fifteen years period from 1999 to 2013. This study used Easton and Harris (1991) formal valuation model. Panel data regression analysis technique was applied to test the relative information content of each performance measure to identify the best performance measure which could explain the stock returns in Sri Lanka. The study revealed that the EPS and ROI are significant performance measures and the EPS is the best performance measure which could explain the significant variations of stock returns in Sri Lanka. The results suggest that the market participants in the Colombo Stock Exchange should pay more attention on EPS and ROI. Meantime they must consider other determinants to develop their investment strategies.
\end{abstract}

Keywords: Earnings per share, Return on equity, Return on investment, Sri Lanka, Stock Return, Value Relevance

\section{Introduction}

The value relevance of accounting information in explaining stock returns has become an important area of study among accounting and finance researchers. The accounting information has been used in measuring organizational performance and in other decisions like investment decisions by individuals and corporations worldwide since early 1900 (Epstein (1925, 1930), Sloan (1929)). However the value relevance of accounting information has been extensively studied in accounting and finance literature after the seminal work of Ball and Brown (1968) and Beaver (1968). Ball and Brawn (1968) found that the information contained in the annual income numbers is useful and they concluded that the changes in earnings are associated with stock returns. After Ball and Brown (1968), Beaver (1968) empirically examined the extent to which common stock investors perceive accounting earnings to possess informational value by directing the attention to the investor reaction to earnings announcements.

After the seminal publication of Ball and Brown (1968) and Beaver (1968) the relationship between accounting performance measures and stock returns was initially investigated in the US market and thereafter this relationship was studied in other different international market settings including some Asian stock markets. Lipe (1986) Easton and Harris (1991), Ohson (1991) Cheng, Cheung and Gopalakrishnan (1993) and Ball, Kathori and Watts (1993), Francis and Schipper (1999) are some of the scholars who provided empirical evidences on the positive relationship between accounting performance measures and stock returns for the US markets. The empirical evidences provided by the studies based on the US markets opened the door for investigating the same in various other international market settings. Among others Booth, Broussard and Loistl (1997) extended this analysis to Europe and studied the German stock market; King and Langli (1998) investigated three European 
counties Norway, UK and Germany; Jermakowicz and Gornik-Tomaszewski (1998) examined this in the Poland Stock market; Vafeas, Trigeorgiou \& Georgiou (1998) studied the Cyprus Stock exchange; Cheung, Kim and Lee (1999) investigated this in Japan; Graham and King (2000) investigated six Asian countries namely Malaysia, Thailand, Indonesia, South Korea, Philippines and Taiwan; Chen, Chen and Su, (2001); Chalmers, Navissi and Qu (2010) examined the Chinese Market; Kousenidis, Negakis, and Floropoulos (2000) and Karanikas (2000), studied Greek market; Pritchard (2002) investigated this relationship in three Baltic stock markets; and Ebaid (2012) studied this in Egypt context and found that accounting performance measures are value relevant in explaining stock returns.

Contrary to the strong argument on the value relevance of traditional accounting performance measures in explaining stock returns in different market settings, such performance measures have being criticized by different scholars and practitioners (for example Kaplan (1983, 1984), Fisher and McGowan (1983) and Rappaport $(1981,1986))$ putting forward various reasons like not considering the cost of equity capital, ignorance of the time value of money, extensive reliance on estimates, availability of alternative accounting treatments etc. and argued that accounting performance measures are not value relevant.

Despite the broad and contradicting literature available on the field of value relevance of accounting information in international stock exchanges, the available knowledge on this context in Sri Lanka for Colombo Stock Exchange as an emerging market, is very poor. It was hard to find published studies directly related to this matter. However, Samarakoon (1997) has studied the ability of book to market equity, leverage and earnings price ratio to explain the cross sectional variation in stock returns in Sri Lanka. Fonseka and Tian (2010) have studied the main forecasting factors of stock analysts, and have found that the Price Earnings ratio, dividend yield, return on equity and rate of retained profit are the financial indicators which affected on experts' advice. But Fonseka and Tian (2010) did not investigate empirically the association of these variables with stock market returns in CSE. Manike, Dunusinhe and Ranasinghe (2015) have studied firm specific determinants of stock returns as a comparative analysis of stock market in Sri Lanka and United Kingdom and found that ROA and sales growth rate play a significant role in explaining variation in stock returns in Sri Lankan companies. Threemanna and Gunaratne (2016) have studied the explanatory power of EPS, ROE, ROA and EVA taking the data from the companies registered under the Food, Beverage and Tobacco sector in Colombo Stock Exchange and have reported that EPS and ROE are significant in explaining stock returns.

The in-depth analysis of the literature brought to light that most of the researches on the context of value relevance in accounting performance measures have been conducted in US market and other developed markets. Comparatively less number of studies could be found in relation to emerging markets. Further the literature showed that the value relevance of accounting performance measures are different across countries. Such reasons create an obvious requirement to examine the value relevance of financial performance measures in an alternative institutional setup.

Accordingly the study was conducted with the objective of assessing the value relevance of three commonly used accounting based performance measures, Earnings Per Share (EPS), Return on Equity (ROE) and Return on Investment (ROI) in explaining stock returns in Sri Lanka.

\section{Method}

\subsection{Population and Sample}

The population of the study is all the quoted Public Limited Companies (PLC) listed in the Colombo Stock Exchange (CSE) Sri Lanka. There are 288 companies representing 20 sectors as at 01/10/2013. The sample size of this study was 1695 firm year observations obtained from 113 public limited companies registered in CSE and the sample period spans for 15 years from the year 1998/1999 to the year 2012/2013. This sample was selected using five criterions. The first criterion is how long the company is trading in the CSE. As the sample period spans for 15 years from the year 1998/1999 to 2012/2013, any public limited company quoted on or before $1 / 4 / 1998$ and operates continuously for 15 years period are qualified to consider in the sample of this study. But to calculate the variables under the study it is required to use the data of two prior years' to the sample period. Hence it was required to consider only the companies quoted on or before 1/4/1996 and operating 17 years continuously. The second and third criterion was to exclude the companies registered under the Bank Finance and Insurance sector and Diversified Holdings sector from the sample. The Bank Finance and Insurance sector companies were removed due to the inherent conditions of financial institutes compared to the companies in any other sectors in CSE. This exclusion is empirically supported by the Fogelberg and Griffith (2000) and Bandara and Weerakoon (2011). The companies registered under the Diversified Holdings sector were excluded from this study due to the availability of group financial statements. This may lead to replication error with other 
sectors. The same methodology has followed by Bandara and Weerakoon (2011). Forth criterion is the balance sheet date (financial year end) of the companies. The researcher considered only the companies whose financial year ends as at $31^{\text {st }}$ March each year. Hence the researcher removed all the companies whose financial year ending any dates other than $31^{\text {st }}$ March from the sample of this study. The fifth and last criterion is the availability of all the required data for entire 17 years period to have a strongly balanced panel data set. There were only 113 companies satisfied all five criterions. Accordingly a total of 1695 (113 X 15=1695) firm-year observations were considered as the final sample of this study.

\subsection{Data and Data Collection}

The entire study was based on secondary data. The required secondary data was collected from two main sources namely the data library of the CSE and the published financial statements of the companies considered in the sample of the study. Finally the relevant calculations were made by the researcher using Excel worksheets to derive the variables used in this study.

\subsection{Variables Definition and Calculation}

The dependent variable of the study is annual stock returns of the companies listed in CSE. The stock return calculation was based on the mostly applied reinvestment assumption. All the types of remittances such as Dividend Payment, Bonus Issues, Stock Splits and Right Issues were considered for the calculation of Stock return. As per the Ph.D Thesis of Nimal (2006) the following formula was used to calculate the monthly returns of each company.

$$
R_{i t}=\left[\left(\frac{P_{t} P_{c}\left(1+R_{r}+S_{r}+B_{r}+D_{r}\right)}{P_{0}\left(P_{c}+R_{r} P_{r}\right)}\right)-1\right] \times 100
$$

\section{Where;}

$\mathrm{R}_{\mathrm{it}} \quad$ : Return of the stock $i$ in the month $t$

$\mathrm{P}_{\mathrm{t}} \quad$ : Price of the stock at the end of the month $t \mathrm{P}_{\mathrm{c}}:$ Closing price of the stock on Ex-right date/ the stock price immediately before the ex-right date

$\mathrm{R}_{\mathrm{r}} \quad$ : Right ratio

$\mathrm{S}_{\mathrm{r}} \quad$ : Split ratio

$\mathrm{D}_{\mathrm{r}} \quad$ : Dividend ratio

$\mathrm{Br}$ : Bonus Ratio

$\mathrm{P}_{0}$ : Price of the stock at the beginning of the month $t$

$\mathrm{P}_{\mathrm{r}} \quad$ : Right issue price of a stock

Finally the annual returns were calculated as the aggregation of the monthly returns extending nine months prior to the fiscal year end and three months after the fiscal year end. (ex. Return of the Year 2012/13 was calculated by aggregating the returns of April 2012 to March 2013).

The independent variable of this study is accounting performance measures. EPS, ROE and ROI were the three widely discussed accounting performance measures. Therefore EPS, ROE and ROI were used as the proxy for accounting performance measures in this study. As this study used Easton and Harris (1991) formal valuation model it was required EPS, change in EPS ( $\triangle \mathrm{EPS})$, ROE, change in ROE ( $\triangle \mathrm{ROE}), \mathrm{ROI}$ and change in $\triangle \mathrm{ROI}$ to be used in our model.

The EPS is the portion of a company's net earnings of a period allocated to each outstanding share of common stock (ordinary shares). It is the figure which indicates that how much net profit was generated per each ordinary share in a given period of time. It is calculated by dividing the profit after tax of a company for a given period by average number of common stocks outstanding. However as a mandatory requirement all the quoted public companies in CSE are publishing the EPS for each year in the face of their statement of comprehensive income. Hence the researcher utilized this company calculated EPS in this study. The $\triangle E P S$ indicates a company's earnings growth or decline on per share basis compared to the previous operating year. The $\triangle$ EPS was calculated in this study as the quotient of the difference between the two consecutive observations $\left(\mathrm{EPS}_{\mathrm{t}}-\mathrm{EPS}_{\mathrm{t}-1}\right)$ dividing by the immediately preceding year's observation $\left(\mathrm{EPS}_{\mathrm{t}-1}\right)$. 
The ROI indicates the net profits earned as a percentage of total investment. The ROI can be calculated by dividing the net earnings of a period by invested capital or the amount of total assets. This study used net profit after tax and average total assets to calculate the ROI for each company for each year. The $\Delta$ ROI is the incremental profits per annum earned on total investment. The $\Delta$ ROI was calculated in this study as the quotient of the difference between the two consecutive observations $\left(\mathrm{ROI}_{\mathrm{t}}-\mathrm{ROI}_{\mathrm{t}-1}\right)$ dividing by the previous time period observation $\left(\mathrm{ROI}_{\mathrm{t}-1}\right)$.

The ROE indicates the return a company is generating on the equity shareholders' investment. It was calculated by dividing the Profit after tax by Average shareholder's equity. The change in ROE indicates the incremental return a company is generating on the equity shareholders' investment. The $\triangle \mathrm{ROE}$ was calculated as the quotient of the difference between the two consecutive observations $\left(\mathrm{ROE}_{\mathrm{t}}-\mathrm{ROE}_{\mathrm{t}-1}\right)$ dividing by the previous time period observation ( $\left.\mathrm{ROE}_{\mathrm{t}-1}\right)$.

\subsection{Statistical Methods of Data Analysis}

Descriptive statistics, correlation analysis and panel data regression analysis were used in this study. Four regression equations were developed based on the four hypothesis of the study. The regression equations were developed according to the Easton and Harris (1991) formal valuation model and panel data regression analysis technique was used to analyze the data. The four regression equations are shown below.

$$
\begin{gathered}
\mathrm{R}_{\mathrm{jt}}=\mathrm{c}_{\mathrm{t} 0}+\mathrm{c}_{1} \mathrm{EPS}_{\mathrm{it}} / \mathrm{p}_{\mathrm{it}-1}+\mathrm{c}_{2} \Delta \mathrm{EPS}_{\mathrm{it}} / \mathrm{P}_{\mathrm{it}-1}+\mathrm{e}_{\mathrm{it}} \\
\mathrm{R}_{\mathrm{jtt}}=\mathrm{d}_{\mathrm{t} 0}+\mathrm{d}_{1} \mathrm{ROE}_{\mathrm{it}}+\mathrm{d}_{2} \Delta \mathrm{ROE}_{\mathrm{it}}+\mathrm{e}_{\mathrm{it}} \\
\mathrm{R}_{\mathrm{jt}}=\mathrm{e}_{\mathrm{t} 0}+\mathrm{e}_{1} \mathrm{ROI}_{\mathrm{it}}+\mathrm{e}_{2} \Delta \mathrm{ROI}_{\mathrm{it}}+\mathrm{e}_{\mathrm{it}} \\
\mathrm{R}_{\mathrm{jt}}=\mathrm{n}_{\mathrm{t} 0}+\mathrm{c}_{1} \mathrm{EPS}_{\mathrm{it}} / \mathrm{p}_{\mathrm{it}-1}+\mathrm{c}_{2} \Delta \mathrm{EPS}_{\mathrm{it}} / \mathrm{P}_{\mathrm{it}-1}+\mathrm{d}_{1} \mathrm{ROE}_{\mathrm{it}}+\mathrm{d}_{2} \Delta \mathrm{ROE}_{\mathrm{it}}+\mathrm{d}_{1} \mathrm{ROE}_{\mathrm{it}}+\mathrm{d}_{2} \Delta \mathrm{ROI}_{\mathrm{it}}+\mathrm{e}_{\mathrm{it}}
\end{gathered}
$$

Where, for all regression models;

$\mathrm{R}_{\mathrm{it}}=$ The annual compounded returns for firm i time $\mathrm{t}$.

$\mathrm{P}_{\mathrm{it}-1}=$ The market value per share of firm $\mathrm{i}$ at the first trading day of the ninth month prior to fiscal year end.

EPS $_{\text {it }} \quad=$ The earnings per share of a firm $\mathrm{i}$ at time $\mathrm{t}$.

$\triangle \mathrm{EPS}_{\mathrm{it}} \quad=$ The change in earnings per share of a firm $\mathrm{i}$ over period $\mathrm{t}-1$ to $\mathrm{t}$.

$\mathrm{ROE}_{\mathrm{it}} \quad=$ The return on equity of firm at time $\mathrm{t}$.

$\Delta \mathrm{ROE}_{\mathrm{it}}=$ The change in ROE of a firm i over period t -1 to $\mathrm{t}$.

$\mathrm{ROI}_{\mathrm{it}} \quad=$ The return on investment of firm i at time $\mathrm{t}$.

$\Delta \mathrm{ROI}_{\mathrm{it}} \quad=$ The change in ROI of a firm i over period t-1 to $\mathrm{t}$.

All these regression models were tested for multi-colinearity using the variance inflation factor (VIF).

EPS and change in EPS has been deflated by the price at the beginning of the return period according to the Easton and Harris (1991). ROE, change in ROE, ROI and change in ROI were not deflated by the beginning of the period price because ROE and ROI have already divided by the equity capital and total average assets. The same approach has been followed by Maditinos, Sevic and Theriou, (2009).

The researcher started the analysis of data by testing few diagnostic tests namely Harris- Tzavalis unit root test Breitung's unit root, Test of Multy-colinearity, Fisher-F test and Breusch, Pagan Lagrangian Multiplier test (LM Test) and Hausman Specification Test. The Harris- Tzavalis unit root test and the Breitung's unit root test were used to test whether the panel data set used in this study is containing unit roots. The test of Multy-colinearity was done by analyzing the variance inflation factor. The Fisher $-\mathrm{F}$ test, Breusch and Pagan Lagrangian Multiplier test (LM Test) and The Hausman specification test were used to select the suitable regression model which fits to the available panel data set of the study. Accordingly the Fisher $-\mathrm{F}$ test was used to select a model out of pooled OLS model and fixed effect regression model and Breusch and Pagan Lagrangian Multiplier test (LM Test) for random effects was used to decide whether to use random effects regression model or simple OLS regression model.

As the Fisher $-\mathrm{F}$ test statistics recommended the fixed effect regression model and the Breusch and Pagan LM Test recommended the random effect regression model, the researcher used Hausman specification test to decide the applicable model out of fixed effect regression model and random effect regression model. Based on the results of the Hausman test the fixed effect regression model was selected in this study to carry on the statistical analysis. 


\section{Results}

This study used uni-variant analysis, bi-variant analysis and multi-variant analysis by utilizing different statistical techniques. The descriptive statistics were used for the uni-variant analysis and the correlation analysis was used for the bi-variant analysis. The fixed effect regression model was used for multi-variant analysis.

The table 1 below provides the summary of descriptive statistics of the dependent variable, return and the independent variable performance measures.

Table1. Descriptive statistics

The summary of the descriptive statistics for the Return and the independent variables namely EPS, $\triangle \mathrm{EPS}, \mathrm{ROE}, \triangle \mathrm{ROE}, \mathrm{ROI}$ and $\triangle \mathrm{ROI}$ of the sample companies whose shares are traded in CSE are presented in this table.

\begin{tabular}{llllllll}
\hline Variable & Return & EPS & $\Delta$ EPS & ROE & $\Delta$ ROE & ROI & \multicolumn{1}{c}{$\Delta$ ROI } \\
\hline Mean & 37.3078 & 0.1185 & 123602.4 & 7.37 & -0.155 & 13.87 & 28.82 \\
Standard & 93.38 & .8486 & $1.08 \mathrm{e}+07$ & 79.356 & 15.9 & \\
Deviation & & & & & & \\
Minimum & -136.23 & -6.101 & $-1.94 \mathrm{e}+08$ & -1784.656 & -239.29 & -288.65 \\
Maximum & 1111.034 & 20.36 & $1.99 \mathrm{e}+08$ & 1617.116 & 250.8745 & 281.17 & -116.1456 \\
\hline
\end{tabular}

The descriptive statistics which have been provided in the table 1 above clearly show that the EPS has the lowest standard deviation while the highest is reported in ROE among the independent variables. Further this result reports that the standard deviation of dependent variable is greater than the independent variables.

The Pearson Correlation Coefficient was used to identify the relationship between the dependent variable, stock return and the each performance measures used as proxy for independent variable. The results are shown in the table 2 below.

Table 2. Correlation coefficients

The Pearson Correlation Coefficient between stock return and each independent variable are presented in this table. Further this table presents the pair wise correlation of all the variables.

\begin{tabular}{|c|c|c|c|c|c|c|c|}
\hline Variable & Return & EPS & $\triangle \mathrm{EPS}$ & ROE & $\triangle \mathrm{ROE}$ & ROI & $\Delta \mathrm{ROI}$ \\
\hline Return & 1 & & & & & & \\
\hline EPS & $0.069^{* * *}$ & 1 & & & & & \\
\hline$\triangle \mathrm{EPS}$ & $0.062^{* *}$ & $0.05^{* *}$ & 1 & & & & \\
\hline ROE & 0.019 & $0.08^{* * *}$ & 0.006 & 1 & & & \\
\hline$\Delta \mathrm{ROE}$ & 0.04 & $0.074^{* * *}$ & 0.007 & $0.19^{* * *}$ & 1 & & \\
\hline ROI & 0.030 & $0.075^{* * *}$ & -0.008 & $0.04^{*}$ & 0.02 & 1 & \\
\hline$\Delta \mathrm{ROI}$ & $0.07^{* * *}$ & $0.115^{* * *}$ & 0.014 & $0.05^{* * *}$ & $0.6^{* * *}$ & $0.08 * * *$ & 1 \\
\hline
\end{tabular}

N.B: The correlations between each pair of variables were measured at 10 percent, 5 percent and 1 percent significant levels. The resulted correlation coefficient values that are significant at the 1 percent level have been marked with $* * *$, significant at 5 percent level have been marked with ** and significant at 10 percent level are marked with *.

The results of the Pearson correlation analysis presented in table 2 above shows that all the independent variables are positively correlated with stock return but the value is very low (week positive correlation). However, only the correlation coefficient of EPS and $\triangle$ ROI with stock return have shown significant at $99 \%$ confidence level and $\triangle$ EPS is significant at $95 \%$ confidence level. As per the results presented in table 2 above the correlation between each independent variable is also positive other than the correlation between ROI and $\triangle E P S$.

The major objective of this study is to identify the significance of the accounting information in explaining stock returns in Sri Lanka. This study used three accounting performance measures as the proxy for accounting information, EPS, ROE and ROI. Accordingly, to achieve this objective the relative information content were tested using three fixed effect regression models where the results are shown in the table 3 , table 4 and table 5 below. Further the researcher tested the value relevance of all three traditional accounting performance measures together and then respective results are shown in the table 6 below. 
Table 3. Fixed effect regression model of EPS and Stock Return

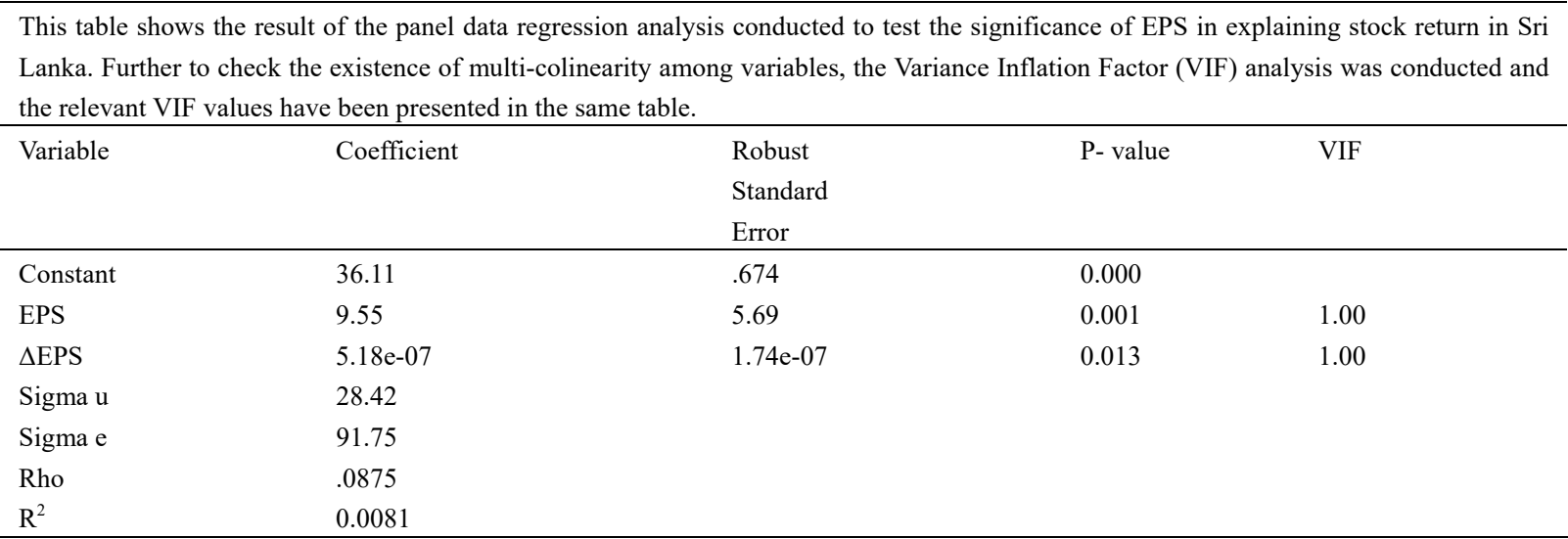

$\mathrm{VIF}>10$ indicates presence of multi-collinearity.

$$
\mathrm{R}_{\mathrm{it}}=36.11+9.55 \mathrm{EPS}+5.18 \mathrm{e}-07 \Delta \mathrm{EPS}
$$

The results of the estimated fixed effect regression model is presented in Table 3 above which was regressed on the stock returns (dependent variable) with the EPS together with the change in EPS to test the hypothesis that the EPS is significant in explaining the cross sections of stock returns in Sri Lanka. The reported results provide evidence to prove that both EPS and the $\triangle$ EPS are influential variables to stock returns. However this result revealed that the model could explain only a 0.81 percent return variation in total. The intra-class correlation known as rho is 8.75 percent which is the variance due to the differences across companies and the total variance due to cross sections is (sigma u) 28.42 percent.

Table 4. Fixed effect regression model of ROE and Stock Return

\begin{tabular}{|c|c|c|c|c|}
\hline Variable & Coefficient & $\begin{array}{l}\text { Robust } \\
\text { Standard } \\
\text { Error }\end{array}$ & P-value & VIF \\
\hline Constant & 37.24 & 0.1674 & 0.000 & \\
\hline ROE & 0.0136 & 0.0225 & 0.545 & 1.04 \\
\hline$\Delta \mathrm{ROE}$ & 0.2152 & 0.0933 & 0.023 & 1.04 \\
\hline Sigma u & 28.0126 & & & \\
\hline Sigma e & 92.1872 & & & \\
\hline Rho & 0.0845 & & & \\
\hline $\mathrm{R}^{2}$ & 0.0017 & & & \\
\hline
\end{tabular}

VIF $>10$ indicates presence of multi-collinearity.

$$
\mathrm{R}_{\mathrm{it}}=37.24+0.0136 \mathrm{ROE}+0.2152 \Delta \mathrm{ROE}
$$

As per the results of the estimated fixed effect regression model presented in the table 4 which was regressed on the stock returns (dependent variable) with the ROE together with the change in ROE to test the hypothesis that the ROE is significant in explaining the cross sections of stock returns in Sri Lanka the researcher failed to reject the null hypothesis. Hence the researcher failed to prove that that ROE is a significant performance measure in explaining the cross section of stock returns in Sri Lanka. However the reported results revealed that though ROE is not significant in this model $\triangle \mathrm{ROE}$ is significant as the $\mathrm{P}$ value is 0.023 . But the model could explain only a 0.17 percent variation of stock returns. The variance due to the differences across companies is 8.45 percent (rho) and the total variance due to cross sections is (sigma u) 28.01 percent. 
Table 5. Fixed effect regression model of ROI and stock return

This table presents the result of the panel data regression analysis conducted to test the significance of ROI in explaining stock returns in Sri Lanka. To check the existence of multi-colinearity among variables, the Variance Inflation Factor (VIF) analysis was conducted and the relevant VIF values have been presented in the same table.

\begin{tabular}{lllll}
\hline Variable & Coefficient & $\begin{array}{l}\text { Robust } \\
\text { Standard } \\
\text { Error }\end{array}$ & P-value & VIF \\
\hline Constant & 33.6057 & 1.6663 & 0.000 & 1.01 \\
ROI & 0.267 & .1201 & 0.028 & 1.01 \\
$\Delta$ ROI & 0.689 & .2367 & 0.004 & \\
Sigma u & 28.8473 & & & \\
Sigma e & 91.8997 & & & \\
Rho & .0897 & & & \\
$\mathrm{R}^{2}$ & 0.0038 & & & \\
\hline
\end{tabular}

VIF $>10$ indicates presence of multi-collinearity.

Rit $=33.6057+0.267 \mathrm{ROI}+0.689 \Delta \mathrm{ROI}$

As per the results presented in the table 5 the null hypothesis is rejected in favor of the alternative hypothesis as the $\mathrm{p}$ value is less than 0.05 . Accordingly the results prove that both the ROI and the $\Delta \mathrm{ROI}$ are influential variables to stock return. According to the results of the statistical analysis one percent increase in ROI across time and between companies leads to change the return positively by 0.267 percent while one percent increase of $\Delta \mathrm{ROI}$ across time and between companies will lead to increase the return by 0.689 percent. Further the results revealed that the model could jointly explain only a 0.38 percent return variation. The intra-class correlation known as rho is 8.97 percent which is the variance due to the differences across companies and the total variance due to cross sections is (sigma $\mathrm{u}$ ) 28.85 percent.

Table 6. Fixed effect regression model of EPS, ROE and ROI with Stock return

This table presents the result of the regression analysis conducted to identify the significance of EPS, ROE and ROI together in explaining stock returns in Sri Lanka. The results of the Variance Inflation Factor (VIF) analysis conducted to check the existence of multi-colinearity among variables have been presented in the same table.

\begin{tabular}{llll}
\hline Variable & Coefficient & $\begin{array}{l}\text { Robust } \\
\text { Standard } \\
\text { Error }\end{array}$ & P- value \\
& & 1.4419 & 0.000 \\
\hline Constant & 32.8915 & 5.1870 & 0.0123 \\
EPS & 8.0602 & $1.71 \mathrm{e}-07$ & 0.003 \\
$\Delta$ EPS & $5.22 \mathrm{e}-07$ & 0.0175 & 0.597 \\
ROE & 0.0093 & 0.1055 & 0.961 \\
$\Delta$ ROE & 0.0052 & 0.1220 & 0.052 \\
ROI & 0.2399 & 0.3003 & 0.058 \\
$\Delta$ ROI & 0.5745 & & 1.00 \\
Sigma u & 29.0273 & & 1.05 \\
Sigma & 91.5853 & & 1.01 \\
Rho & .0913 & 0.03 & \\
R $^{2}$ & 0.0107 & & \\
\hline
\end{tabular}

In this model the stock return (dependent variable) was regressed with all traditional accounting performance measures considered in the study- the EPS, ROE and ROI together with their respective change variables of all three variables in order to test whether the traditional accounting performance measures together can be used in explaining the stock returns in Sri Lanka. The results presented in table 6 shows that EPS, $\triangle E P S$, ROI and $\triangle$ ROI are significant in this model. Those are the only influential variable in determining the stock returns out of the included traditional accounting performance measures in the model and had a strong positive significant association with stock returns. The $\mathrm{P}$ value of those four variables is less than 0.05 . ROE and $\triangle \mathrm{ROE}$ are not significant even in this combined model. Further the results revealed that all these variables could jointly explain 
only a 1.07 percent return variation. The intra-class correlation known as rho is 9.13 percent which is the variance due to the differences across companies and the total variance due to cross sections is (sigma u) 29.02 percent.

\section{Discussion}

The value relevance of accounting information has become an important and inconclusive area of study among accounting researchers. Hence this study aimed at giving conclusion on the value relevance of accounting information in explaining stock returns in Sri Lanka taking three accounting performance measures, EPS, ROE and ROI as the proxy for accounting information.

The relative information content test revealed that only two regressions models out of four tested models are significant. It was observed that similar results have been obtained by the Maditinos, Sevic and Theriou, (2009). They have reported that ROE is not statistically significant while EPS and ROI are significant in explaining stock returns in Athens Stock exchange. However they have not tested the combine effect of all three measures together as our forth model. The EPS is the best performance measures in Sri Lankan context which has a positive relationship with stock returns. This result is tally with the reported results of Pritchard (2002) for Baltic Markets and Threemanna and Gunaratne (2016) for Food, Beverage and Tobacco sector compnies in CSE. The value relevance of EPS in explaining stock returns has been reported by Pritchard (2002) for three Baltic markets, Lithuania, Latvia, and Estonia. The value relevance of EPS and ROI has been revealed by Chen and Dodd $(1996,1997)$. Our results are too similar with the findings of Chen and Dodd $(1996,1997)$. In general, the reported results of this study on the value relevance of accounting performance measures are similar to the findings of the scholars who reported that there is a positive relationship between accounting performance measures and stock returns in different stock exchanges.

\section{Conclusion}

The general objective of this study was to identify the value relevance of accounting information on stock returns in Sri Lanka. This was achieved by testing the relative information content of each performance measure concerned in this study by using three fixed effect regression models and testing the incremental information content using another fixed effect regression model taking all three performance measures together. The relative information content test revealed that EPS, and ROI are associated with stock returns and the EPS showed the highest explanatory power ( $\mathrm{R}$ square value is 0.0081 ) out of the three variables considered individually. The incremental information content test revealed that when all three measures considered together in a single model the explanatory power will increase (R square value is 0.0107 ). However this model too concludes that only EPS and ROI are significant in explaining stock returns. The $\mathrm{P}$ value of ROE is greater than 0.05 . Accordingly it can be concluded that the EPS and ROI are the accounting information which has value relevance.

In conclusion, as this study revealed that EPS and ROI are value relevant in explaining stock returns in Sri Lanka, the researcher recommends the market participants in the CSE to pay considerable attention on EPS and ROI in making decisions. Further the researcher advices them to consider other determinants adequately in order to reach their investments goals successfully.

\section{Acknowledgments}

I am gratefully indebted to Ms. LMCS Manike, senior lecturer at The University of Sabaragamuwa, Sri Lanka who rendered immense support in data analysis and interpretation. Ms. LMCS Manike was instrumental in giving direction on panel data analysis techniques and interpretation used in this study. I am also indebted to $\mathrm{Mr}$. K.D.U.D. Fernando, Lecture at The University of Sabaragamuwa, Sri Lanka.

I am particularly indebted to Dr. DAM Perera, senior lecturer at The University of Wayamba, Sri Lanka who always stood ready to lend an ear and provide advice when asked. He too rendered a priceless support in every aspect of this study.

Finally, the completion of this task with an academic career would have been impossible without the sacrifice, love and support of my husband Mr. BGPSK Gamaarachchi. He is my best friend, my strongest supporter, my comfort, and my strength. Thank you for pushing me to pursue my dreams.

This paper is a presentation of an original work of the first author conducted with the supervision of the second author. The supervision was consistent with the normal supervisory practice of the University of Sri Jayewardenepura Sri Lanka.

\section{References}

Ball, R., \& Brown, P. (1968). An empirical evaluation of Accounting Income Numbers. Journal of Accounting 
Research, 6(2), 159-178. https://doi.org/10.2307/2490232

Ball, R., Kothary, S. P., \& Watts, R. L. (1993). Economic Determinants of the Relation between Earnings changes and Stock Returns. The Accounting Review, 68(3).

Bao, B. H., \& Bao, D. H. (1998). Usefulness of Value Added and Abnormal Economic Earnings: An Empirical Examination. Journal of Business Finance and Accounting, 25(1-2), 251-265. https://doi.org/10.1111/1468-5957.00186

Bao, B., \& Chow, L. (1999). The usefulness of earnings and book value for equity valuation in emerging capital markets: evidence from listed companies in the people's republic of China. Journal of International Financial Management and Accounting, 10(2), 85-104. https://doi.org/10.1111/1467-646X.00045

Beaver, W. H. (1968). The information content of annual earnings announcements. Journal of Accounting research, 6, 67-92. https://doi.org/10.2307/2490070

Booth, G. G., Broussard, J., \& Loistl, O. (1997). Earnings and Stock Returns: Evidence from Germany, European Accounting Review, 6(4), 589-603. https://doi.org/10.1080/09638189700000002

Chalmers, K., Navissi, F., \& Qu, W. (2010). Value relevance of accounting information in China pre and post 2001 accounting reforms. Managerial Auditing Journal, 25(8), 792-813. https://doi.org/10.1108/02686901011069551

Chen, C. J. P., Chen, S., \& Su, X. (2001). Is accounting information value relevant in the emerging Chinese stock market? Journal of International Accounting Auditing \& Taxation, 10(1), 1-22. https://doi.org/10.1016/S1061-9518(01)00033-7

Chen, S., \& Dodd, J. L. (1997). Economic value added: An empirical examination of a new corporate performance measure, Journal of Managerial Issues, 9(3), 318-333.

Cheng, C. S. A., Cheung, J. K., \& Gopalakrishnan, V. (1993). On the usefulness of operating income, Net income and comprehensive income in explaining stock returns. Accounting and Business Research, 23(91), 195-203. https://doi.org/10.1080/00014788.1993.9729879

Cheung, J. K., Kim, J. B., \& Lee, J (1999). The Impact of Institutional Characteristics on Return-Earnings Associations in Japan, The International Journal of Accounting, 34(4), 571-596. https://doi.org/10.1016/S0020-7063(99)00019-9

Dyl, E. A. (1989). Agency, corporate control and accounting methods: The LIFO-FIFO choice. Managerial and Decision Economics, 10, 141-147. https://doi.org/10.1002/mde.4090100209

Easton, P. D., \& Harris, T. S. (1991). Earnings as an explanatory variable for returns, Journal of Accounting Research, 29(1), 19-36. International Journal of Accounting, 34(4), 571-596.

Ebaid, I. E. (2012). The value relevance of accounting-based performance measures in emerging economies The case of Egypt. Management Research Review, 35(1), 69-88. https://doi.org/10.1108/01409171211190814

Ely, K., \& Waymire, G. (1999). Accounting standard setting organizations and earnings relevance: longitudinal evidence from NYSE common stocks, 1927-93. Journal of accounting research, 37(2), 293-317. https://doi.org/10.2307/2491411

Epstein, R. C. (1925). Industrial profits in 1917. The Quarterly Journal of Economics, 39(3), 241-266. https://doi.org/10.2307/1884874

Epstein, R. C. (1930). Statistical lights on profits in 1917, The Quarterly Journal of Economics, 44(2), 329, Retrieved from http://www.jstor.org/stable/1885252

Fisher, F. M., \& McGowan, J. J. (1983). On the misuse of accounting rates of infer monopoly profits. The American economic review, 73(1), 82-97.

Francis, J., \& Schipper, K. (1999). Have financial statements lost their relevance? Journal of Accounting Research, 37(2), 319-352. https://doi.org/10.2307/2491412

Graham, R. C., \& King, R. D. (2000). Accounting practices and the market valuation of accounting numbers: evidence from Indonesia, Korea, Malaysia, the Philippines, Taiwan, and Thailand. The International Journal of Accounting, 35(4), 445-470. https://doi.org/10.1016/S0020-7063(00)00075-3

Hunt, H. G., (1985). Potential determinants of corporate inventory accounting decisions. Journal of Accounting Research, 23, 448-467. https://doi.org/10.2307/2490820 
Jensen, M. C., \& Murphy, K. J. (1990). CEO incentives-it's not how much you pay but how. Harvard Business Review, 68, 138-149. https://doi.org/10.1111/j.1745-6622.1990.tb00207.x

Jermakowicz, E. K., \& Gornik-Tomaszewski, S. (1998). Information Content of Earnings in the Emerging Capital Market: Evidence from Warsaw Stock Exchange, Multinational Finance Journal, 2(4), 245-267. https://doi.org/10.17578/2-4-1

Jusoh, R., Ibrahim, D. N., \& Zainuddin, Y. (2008). The performance consequence of multiple performance measures usage: Evidence from the Malaysian manufacturers. International Journal of Productivity and Performance Management, 57(2), 119-136. https://doi.org/10.1108/17410400810847393

Kaplan, R. S. (1983). Measuring Manufacturing Performance. A New Challenge for Management Accounting Research. The Accounting Review, 686-705.

Kaplan, R. S. (1984). The Evolution of Management Accounting. The Accounting Review, 59(3), 390-418. https://doi.org/10.1007/978-1-4899-7138-8_27

Kaplan, R. S., \& Norton, D. P. (1992). The balance score card-measures that drive performance. Harvard Business Review, 70, 71-99.

Karanikas, E. (2000). CAPM Regularities for the Athens Stock Exchange. Spoudai, 50(1/2), 40-57.

King, R. D., \& Langli, J. C. (1998). Accounting diversity and firm valuation. The International Journal of Accounting, 33(5), 529-567. https://doi.org/10.1016/S0020-7063(98)90012-7

Kousenidis, D., Negakis, C., \& Floropoulos, I. (2000). Size and Book-to-Market Factors in the Relationship between Average Stock Returns and Average Book Returns: Some Evidence from an Emerging Market. European Accounting Review, 9(2), 225-243. https://doi.org/10.1080/09638180050129882

Lipe, R. C. (1986). The information contained in the components of earnings, Journal of Accounting Research, 24, 37-64. https://doi.org/10.2307/2490728

Maditinos, D. I., Sevic, Z., \& Theriou, N. G. (2009). Modelling Traditional accounting and modern value based performance measures to explain stock market returns in the Athens stock Exchange (ASE). Journal of Modelling in Management, 4(3), 182-20. https://doi.org/10.1108/17465660911006431

Maditions, I. D., Sevic, Z., \& Theriou, N. G. (2006). The Introduction of Economic Value Added in the Greek Corporate Sector. The South European Review of Business \& Accounting, 4(2), 1-11.

Menike, L. M. C. S., Dunusinghe, P. M., \& Ranasinghe, A. (2015). Macroeconomic and Firm Specific Determinants of Stock Returns: A Comparative Analysis of Stock Markets in Sri Lanka and in the United Kingdom. Journal of Finance and Accounting, 3(4), 86-96. https://doi.org/10.11648/j.jfa.20150304.14

Ohlson, J. A. (1991). The theory of value and earnings, and an introduction to the Ball-Brown analysis, Contemporary Accounting Research, 8(1), 1-19. https://doi.org/10.1111/j.1911-3846.1991.tb00831.x

Pritchard, N. J. (2002). The relationship between accounting numbers and returns in the Baltic stock markets.

Rappaport, A. (1981). Selecting strategies that create shareholder value, Harvard Business Review, 59(3), $139-49$.

Rappaport, A. (1986). Creating Shareholder Value (1st ed.). New York, NY: The Free Press.

Samarakoon, L. P. (1997). The cross-section of expected stock returns in Sri Lanka. Sri Lanka Journal of management, 2(3), 234-250.

Sloan, L. (1929). Corporate Profits: A Study of Their Size, Variation, Use, and Distribution in a Period of Prosperity. New York, NY: Harper \& Brothers Publishers.

Stephens, K. R., \& Bartunek, R. R. (1997). What is economic value added? A practitioner's perspective. Business Credit, 4, 39

Stewart, G. B. (1994). EVA: Fact and fantasy, Journal of Applied Corporate Finance, 7(2), 71-84. https://doi.org/10.1111/j.1745-6622.1994.tb00406.x

Threemanna, T. H. M. S., \& Gunaratne, Y. M. C. (2016). Performance measures and stock returns: Evidence from Beverage Food and Tobacco Sector of Sri Lanka. International Journal of Research in Management, 1(6), 15-17.

Tortella, B., \& Brusco, S. (2003). The Economic value Added (EVA): An Analysis of market reaction, Advances in Accounting, 20(3), 265-290. https://doi.org/10.1016/S0882-6110(03)20012-2 
Vafeas, N., Tringeorgis, L., \& Georgiou, X. (1998). The usefulness of earnings in stock returns in an emerging market: The case of Cyprus.

\section{Copyrights}

Copyright for this article is retained by the author(s), with first publication rights granted to the journal.

This is an open-access article distributed under the terms and conditions of the Creative Commons Attribution license (http://creativecommons.org/licenses/by/4.0/). 